\title{
Effect of Perceptual Exercise Program on Basic Motor Skills in a Child with Intellectual Disability: Single Subject Research Design
}

\author{
Sang-Hyup Song ${ }^{1 *}$ \\ ${ }^{1}$ Department of Physical Education, Seowon University
}

Received: December 27, 2019

Accepted: January 14, 2020

Published online: January 31, 2020

ABSTRACT

Keywords:

Basic Motor Skills

Intellectual Disability

Perceptual Exercise

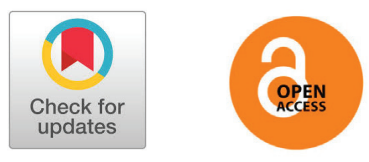

OBJECTIVES The purpose of this study was to identify the effect of perceptual exercise program on basic motor skills in a child with intellectual disability.

METHODS One child with intellectual disability was participated in this study. Perceptual exercise program was performed 60 minutes per session, twice a week for 32 weeks. To evaluate the basic motor skills of the subject pre and post the exercise, subject was measured in six areas of operational skills including throwing, catching, kicking, hitting, bouncing, and rolling; two areas of movement skills including balance beam, walking backward; and two areas of stabilization skills including standing with one leg and escaping.

RESULTS The subject who participated in this study gained $60 \%$ throwing, $60 \%$ catching, $80 \%$ kicking, $60 \%$ hitting, $80 \%$ bouncing, and $60 \%$ rolling was increased respectively in the operational skills and $80 \%$ balance beam, $100 \%$ walking backward in the movement skills, and $80 \%$ standing with one leg, $100 \%$ escaping in the stabilization skills.

CONCLUSIONS Those results show that perceptual exercise program was positive influence on operational skills, movement skills and stabilization skills in a child with intellectual disability.

(c) The Asian Society of Kinesiology and the Korean Academy of Kinesiology

\section{서론}

지적장애 아동의 지적기능은 평균과 비교하여 낮고 적응 기능의 한계로 인하여 의사 소통, 자조, 가사, 사 회기술, 지역사회 활동, 자율성, 건강과 안전, 기능적 학 업, 여가 및 직업 가운데 두 가지 이상의 영역에서 기능 적으로 한계가 있다[1]. 또한, 전체적인 발달이 지연되 고 기초적인 감각기능과 운동 기능적 측면에서 특히 두 드러진 결함을 보이며 장애의 정도가 심해질수록 지체 가 더욱 심각해진다[2]. 이러한 이유로 지적장애 아동 은 자신이 가지고 있는 신체적, 정신적 제한점으로 신

*Correspondence: Sang-hyup Song, Physacal Education, Seowon University, 377-3 Musimseoro, Heungdeok-gu, Cheongju, Chungbuk; Tel: +82-10-9557-2425 E-mail: yo-hyup@hanmail.net
체활동 참여의 기회가 줄어들고 이로 인한 자신감의 결 여, 독립심 저하 등 여러 가지 문제점들에 직면하게 되 어 결국 삶의 질이 비장애인과 비교하여 많이 떨어진다 [3]. 이렇듯 지적능력의 발달지체는 전반적인 운동기 능의 발달지체를 동시에 수반하고 있기 때문에 장애 정 도가 심할수록 신체발달과 운동기능이 매우 열등한 특 징을 보인다[4].

지각운동(perceptual motor)이란 감각정보를 받아 들여 해석하고 반응하는 개인의 능력으로 정의되며, 지 각은 정보를 알거나 해석하는 것을 의미하고 운동은 움 직임 또는 운동반응을 말한다[5]. 지각운동을 발달시키 기 위해서는 공간에서의 움직임과 자세조절을 위한 고 유계, 시각계, 전정계의 처리 및 통합뿐만 아니라 다양 
한 감각계를 통한 환경의 변화와 정보들을 정확하게 감 지하는 능력이 요구된다[6]. 특히 지적장애 아동의 경 우 물체조작운동 기술능력 수준이 비장애아동의 4-5년 정도 떨어지는 수준으로 비장애아동들과 함께 또는 지 적장애 아동 간의 체육활동 및 스포츠활동 참여가 어렵 다[7]. 이러한 측면에서 신체활동은 학습과 동시에 생 활이므로 지각운동은 지적장애 아동을 위한 교육에 있 어서 필수적인 부분이라 할 수 있다. Jeong [8]은 지 적장애인을 대상으로 지각운동발달 특성연구를 통하여 정신연령이 7 세 이후에도 지각운동 능력의 완전한 발 달이 이루어지지 않기 때문에 추가적으로 계속적인 발 달이 가능하다는 점을 보고하였다. 다시 말하면 지각능 력은 후천적으로 발달하므로 반복적인 훈련에 의해 강 화될 수 있으며 아동의 생활연령이나 지능, 지각운동 수 준에 맞는 체계적인 프로그램을 적용한다면 생활연령에 상응한 수준까지 향상 될 수 있다[9]. 또한 지적장애와 같은 발달장애를 가지고 있는 자폐성아동과 뇌병변장애 아동을 대상으로 한 지각운동의 사례를 살펴보면 신체 활동을 통한 움직임교육으로 신체적, 정서적, 사회적 응력, 문제행동 및 주의집중력이 개선되었고 [10], 지 각운동의 기능 중심적 특수체육 활동이 자폐성장애 아 동의 이동운동과 조작운동 기술에 긍정적인 영향을 미 쳤다고 보고하였다[11].

기본운동기술은 걷고 달리기와 같은 이동능력과 던 지고, 차기, 치기와 같은 조작능력 그리고 서있는 자 세에서 수행이 가능한 목표 지향적 움직임을 기본운동 기술이라고 정의하였다[12]. 일반적으로 지적장애 아 동을 포함한 발달장애 아동은 중추신경계 이상으로 신 체적, 정신적 발달이 이루어져야 하는 시기에 정상적인 성장을 하지 못하고 조작능력, 이동능력, 균형능력 등이 또래 아동에 비하여 현저히 저하되어 있다[13]. 이러한 기본이동기술은 아동기에 급속한 발달이 이루어지며 다 양한 신체활동 수행에 직접적인 영향을 미쳐 스포츠 기 술이나 게임 기술에 성공적으로 참여하는데 도움을 주 는 것으로 잘 알려져 있다[14].

이와 같이 지각운동 중심의 신체활동은 장애아동에 게 있어서 꼭 필요하며 이를 기반으로 기본운동기술의 습득은 일상생활 및 스포츠 활동을 위해 매우 중요하다. 최근까지 이러한 문제를 해결하기 위해 다각적인 측면 에서 연구가 지속되어 왔으나 선행연구들은 주로 공격 적 행동, 상동행동 및 자해행동과 같은 문제행동이나 사
회성 발달에 관한 연구가 주를 이루었다. 또한 지적장애 인이 운동을 통해 운동수행능력을 향상시킬 수는 있으 나 낮은 지적 능력과 단기기억으로 인해 운동수행 학습 에 많은 어려움을 겪기 때문에 운동수행능력의 향상을 단기간에는 기대하기 어렵다고 하였다[15].

이러한 관점에서 이 연구에서는 지적장애 아동 1 명 을 대상으로 지각운동 프로그램이 기본운동기술에 미 치는 영향을 32 주간 심층적으로 검토하여 향후 지적장 애 아동을 위한 운동프로그램 개발을 위한 기초자료를 제공하고자 한다.

\section{연구대상}

이 연구의 대상자는 충청남도 소재 $\mathrm{S}$ 센터 소속 초등 학교 6학년 지적장애 아동 1 명을 대상으로 하였다. 대 상자는 특수학급에서 수업을 받고 있으며 학교생활과 일상생활에서 행동문제로 인하여 지도하는데 어려움이 있는 아동이다. Eyberg 아동행동 검사결과 행동문제 심도점수는 148 점이었고 행동문제 개수가 14 점으로 비 교적 높게 평가되었다.

대상자는 생활연령 13세 9개월로 1남 1녀 중 첫째로 출생 시 큰 문제없이 정상적으로 태어났으나 이후 정상 발육발달단계를 보이지 않아 검사를 통하여 원인불명의 지적 장애 2 급 진단을 받았다. 현재 수용언어는 간단한 지시 따르기를 수행하지만 표현언어의 곤란함으로 원활 한 의사소통이 어렵고, 동일단어를 되풀이하여 말하며 상황에 맞지 않게 깔깔거리며 웃는 모습이 자주 관찰된 다. 언어수준은 간단한 모방발화가 가능하지만 자발적 으로 말을 하는 경우는 거의 드물고 자신이 필요한 것이 나 먹고 싶은 것을 요구하거나 좋아하는 노래를 반복적 으로 흥얼거리며 다른 사람들에게서 들었던 대화를 모 방하는 선택적인 발화가 가능한 수준이다. 혼자서 밥을 먹을 수 있지만 자리에 앉아 식사하는 일에 열중하지 못 하여 식사시간이 다소 오래 걸린다. 일상생활에서의 보 행능력과 운동능력은 보통이지만 운동 중 갑자기 자리를 이탈하거나 침을 뱉고 소리를 지르는 문제행동들이 관 찰되고 있다. 주변 사람들과 정상적인 상호작용은 이루 어지지 않지만 관심을 유도하기 위하여 침을 뱉거나 운 동 중 자리를 이탈하고 회피하려는 모습이 관찰 되만 친 근감의 표현으로 선생님을 안아주거나 상대방의 체취를 맡으려는 행동을 수행하기도 한다. 이 연구에 참여하는 부모님과의 상담을 통하여 이 연구의 취지와 내용에 대 
하여 충분히 설명하고 동의를 얻어 이 연구를 진행하였 다. 대상자의 신체적 특성은 <Table 1 >에 제시하였다.

\section{측정도구및방법}

이 연구에 참여한 대상자의 운동능력을 측정하기 위 해 Ulrich [16]가 개발한 TGMD-2(대근육운동발달검 사) 측정표를 기반으로 이 연구의 목적에 맞게 일부 수 정하여 측정하였다. 측정은 모두 2 회씩 측정하였으며,
Table 1. Physical characterlistics of the subject.

\begin{tabular}{ll}
\hline & Subject \\
\hline Gender & Male \\
Age(yrs) & 13.6 \\
Height $(\mathrm{cm})$ & 151.2 \\
Body weight $(\mathrm{kg})$ & 61.9 \\
BMI $\left(\mathrm{kg} / \mathrm{m}^{2}\right)$ & 27.1 \\
\hline
\end{tabular}

Table 2. Operational skills measurement.

\begin{tabular}{|c|c|c|c|c|}
\hline Category & & Measurement Items & Pre-test & Post-test \\
\hline \multirow{12}{*}{ Operational skills } & \multirow[b]{2}{*}{ Throwing } & Throw the tennis ball overhand with one hand. & & \\
\hline & & $\begin{array}{l}\text { * Performance criteria } \\
\text { 1. The windup starts from the bottom of the hand / arm. } \\
\text { 2. Rotate your hips and shoulders with the non-throwable side facing the wall. } \\
\text { 3. Move the weight by pushing forward with the opposite foot of the throwing arm. } \\
\text { 4. After throwing the ball, follow throw diagonally toward the opposite side of the } \\
\text { throwing arm. } \\
\text { 5. Throw the ball over } 8 \mathrm{~m} \text { with one hand. }\end{array}$ & & \\
\hline & \multirow[b]{2}{*}{ Catching } & You can catch the ball. & & \\
\hline & & $\begin{array}{l}\text { * Performance criteria } \\
\text { 1. Reach out in front of your body and bend your elbows flexibly. } \\
\text { 2. Look at the flying ball. } \\
\text { 3. Reach out to receive the ball. } \\
\text { 4. Use only your hands to get the ball. } \\
\text { 5. You can receive a ball falling from } 2 \text { meters. }\end{array}$ & & \\
\hline & \multirow[b]{2}{*}{ Kicking } & You can kick the ball and score the goal at $5 \mathrm{~m}$ in front of you. & & \\
\hline & & $\begin{array}{l}\text { * Performance criteria } \\
\text { 1. Approach the ball at high speed. } \\
\text { 2. There is a momentary lip or wide stride before kicking. } \\
\text { 3. The unfooted foot is placed right next to or behind the ball. } \\
\text { 4. Kick it with the instep or heel of your foot. } \\
\text { 5. The goal can be accurately scored at the goal of } 5 \text { meters.. }\end{array}$ & & \\
\hline & \multirow[b]{2}{*}{ Hitting } & You can hit the ball on the T-bar. & & \\
\hline & & $\begin{array}{l}\text { ** Performance criteria } \\
\text { 1. Hold the bat in the order of the hands you normally use on the hands that you do } \\
\text { not use. } \\
\text { 2. Keep your feet parallel and point to the virtual tossor to the side of the body that } \\
\text { you are not using. } \\
\text { 3. Rotate your shoulders and hips while swinging. } \\
\text { 4. Move the center of gravity towards the forefoot. } \\
\text { 5. Hit the ball with the bat. }\end{array}$ & & \\
\hline & \multirow[b]{2}{*}{ Bouncing } & Bounce continuously in a ball. & & \\
\hline & & $\begin{array}{l}\text { * Performance criteria } \\
\text { 1. Touch the ball with one hand at the waist (belt) height. } \\
\text { 2. Push the ball with your fingertips (not your palm). } \\
\text { 3. Keep the ball in front of or near the side of your main foot. } \\
\text { 4. Do not move your foot to keep hitting the ball. } \\
\text { 5. Control the ball four times in a row. }\end{array}$ & & \\
\hline & \multirow[b]{2}{*}{ Rolling } & Roll the ball to hit the bowling pin 5 meters in front of you. & & \\
\hline & & $\begin{array}{l}\text { 1. Swing the chest towards the bowling pin and swing your dominant hand down / } \\
\text { back behind the torso. } \\
\text { 2. The swinging hand is facing the bowling pins, with the opposite foot forward. } \\
\text { 3. Lower your body by bending your knees. } \\
\text { 4. Roll the ball close to the floor so that it is not bound more than } 10 \mathrm{~cm} \text {. } \\
\text { 5. Set the bowling pin exactly } 5 \text { meters ahead. }\end{array}$ & & \\
\hline
\end{tabular}


항목별 5 가지의 수행기준에 근거하여 수행기준을 만족 할 경우 1 점씩 부과하여 5 개 만족 시 5점, 4 개 만족 시 4 점, 3 개 만족 시 3 점, 2 개 만족 시 2점, 1 개 만족 시 1 점으로 측정하였다. 측정자 간의 오차가 발생할 것을 우 려하여 특수체육 전문가 3 인 중 2 인 이상의 결과를 최 종 수행점수로 결정하였다. 이 연구에서 사용된 측정표 는 〈Table 2〉, 〈Table 3>에 제시하였다.

\section{지각운동 프로그램}

이 연구에서 사용한 지각운동 프로그램은 Jang et al. [17] 의 연구를 참고하여 대상자의 특성을 고려하고 발 달단계에 알맞은 프로그램으로 수정 및 보완하였다. 운 동은 하루 60 분, 주 2 회, 총 32 주간 기초체력 운동과 지각운동을 함께 진행하였으며, 운동 초기 (1 16주)에 는 대상자의 특성을 고려하여 1 단계와 2 단계의 운동을
반복적으로 진행하여 기본개념을 습득할 수 있도록 진 행하였다. 17 32주에는 3단계와 4 단계의 운동을 진행 하였으며 움직임 중심의 동작을 응용하여 진행하였다. 지적장애 아동의 특성상 주의력과 일반화 능력에 결함 이 있어 학습에 어려움을 느끼고 주의집중 시간이 짧으 며 한번 학습한 내용의 저장 혹은 재생 능력이 부족하 여 운동 중 대상자의 컨디션에 따라 흥미와 호기심을 유 발할 수 있도록 수업 분위기를 유도하였다. 이 연구에서 사용한 지각운동 프로그램은 <Table 4 >에 제시하였다.

\section{자료처리}

이 연구에서 측정된 자료는 사전검사를 실시하고 32 주간의 지각운동 프로그램을 적용한 후 사후검사를 실 시하였다. 사전, 사후의 측정결과와 증감의 차이를 비교 하여 비율 $(\%)$ 로 산출하였다.

Table 3. Movement and stabilzation skills measurement.

\begin{tabular}{|c|c|c|}
\hline Category & & Measurement Items \\
\hline \multirow{4}{*}{ Movement skills } & \multirow[b]{2}{*}{ Balance beam walk } & Cross the balance beam in less than 5 seconds. \\
\hline & & $\begin{array}{l}\text { * Performance criteria } \\
\text { 1. Sometimes you lose balance, but soon center. } \\
\text { 2. Use both arms to help balance yourself. } \\
\text { 3. It does not fall from the balance beam. } \\
\text { 4. The gaze stares at the front. } \\
\text { 5. You can walk on balance beam within } 5 \text { seconds. }\end{array}$ \\
\hline & \multirow[b]{2}{*}{ Walk backward } & You can walk straight backwards along a $6 \mathrm{~cm}$ wide line. \\
\hline & & $\begin{array}{l}\text { * Performance criteria } \\
\text { 1. Keep your back straight } \\
\text { 2. The front of the sole touches the ground first. } \\
\text { 3. You can walk cross your feet. } \\
\text { 4. You can walk while keeping your center with both hands. } \\
\text { 5. You can walk straight back along a } 6 \mathrm{~cm} \text { wide line. }\end{array}$ \\
\hline \multirow{4}{*}{ Stabilization skills } & \multirow[b]{2}{*}{ standing with one leg } & You can be standing with single leg for more than 10 seconds. \\
\hline & & $\begin{array}{l}\text { * Performance criteria } \\
\text { 1. Lift the legs that are not supported. } \\
\text { 2. You can stand centered without falling. } \\
\text { 3. Use both arms to balance. } \\
\text { 4. Sometimes lose balance but stand up immediately. } \\
\text { 5. You can stand for more than } 10 \text { seconds. }\end{array}$ \\
\hline & \multirow[b]{2}{*}{ Escaping } & You can avoid seeing the flying ball. \\
\hline & & $\begin{array}{l}\text { * Performance criteria } \\
\text { 1. Do not bow or block your head. } \\
\text { 2. Look at the flying ball. } \\
\text { 3. You can avoid moving your upper body without moving your feet. } \\
\text { 4. You can avoid the ball without losing your center. } \\
\text { 5. You can freely avoid the ball while moving. }\end{array}$ \\
\hline
\end{tabular}


Table 4. Perceptual exercise program.

\begin{tabular}{|c|c|c|c|c|c|c|}
\hline Index & \multicolumn{4}{|c|}{ program } & Intensity & Time(min) \\
\hline Warm up & \multicolumn{3}{|c|}{$\begin{array}{l}\text { Learn your body name } \\
\text { Body range and movement activity }\end{array}$} & $\begin{array}{l}\text { - Face areas (eyes, nose, mouth, forehead, ears) } \\
\text { - Upper body area (neck, shoulder, hand, wrist) } \\
\text { - Lower body (waist, knee, ankle) }\end{array}$ & & 5 \\
\hline & & \multicolumn{2}{|c|}{ Cardiopulmonary endurance } & - treadmill $800 \mathrm{~m}(300 \mathrm{~m}$ run $/ 100 \mathrm{~m}$ walk) & HRmax 60-70\% & \\
\hline & & \multicolumn{2}{|c|}{ Muscle strength } & - squat \& sit up & $20-40$ times $\times 2$ set & \\
\hline & Fitness & \multicolumn{2}{|l|}{ Power } & - air board or box jump & $20-40$ times $\times 2$ set & 20 \\
\hline & & \multicolumn{2}{|l|}{ Balance } & $\begin{array}{l}\text { - single leg balance } \\
\text { - balance beam walk(forward, side, backward) }\end{array}$ & $10-30$ sec & \\
\hline & & \multicolumn{2}{|c|}{ Coordination } & - jump rope(double leg, cross jump, X- figure) & 10-30times & \\
\hline & \multirow{7}{*}{$\begin{array}{l}\text { Perceptual } \\
\text { exercise }\end{array}$} & $\begin{array}{l}\text { Catch } \\
\text { (ball) }\end{array}$ & $\begin{array}{l}\text { Eye-hand coordination } \\
\text { Eye-hand-foot } \\
\text { coordination } \\
\text { Direction perception } \\
\text { Height perception }\end{array}$ & $\begin{array}{l}\text { 1. Seeing the flying ball and receiving it with your } \\
\text { chest } \\
\text { 2. See the flying ball and use only your hands } \\
\text { 3. Receiving balls falling from high places } \\
\text { 4. Get the ball while moving }\end{array}$ & \multirow{7}{*}{$\begin{array}{l}\text { level1, } 2 \\
1-16 \text { week } \\
\text { Static movement }\end{array}$} & \multirow{7}{*}{30} \\
\hline & & $\begin{array}{l}\text { throwing } \\
\text { (ball) }\end{array}$ & $\begin{array}{l}\text { Eye-hand coordination } \\
\text { Body perception } \\
\text { Strength perception } \\
\text { Direction perception } \\
\text { Weight perception }\end{array}$ & $\begin{array}{l}\text { 1. Throwing the ball with both hands in the up, } \\
\text { middle and down directions (away, close, light, } \\
\text { heavy) } \\
\text { 2. Throw the ball with one hand (away, close, } \\
\text { light, heavy) } \\
\text { 3. Throw the ball to the left or right direction (one } \\
\text { hand, two hands) } \\
\text { 4. Hit the target }\end{array}$ & & \\
\hline \multirow[t]{5}{*}{ Main exercise } & & $\begin{array}{l}\text { Rolling } \\
\text { (ball) }\end{array}$ & $\begin{array}{l}\text { Eye-hand coordination } \\
\text { Eye-hand-foot } \\
\text { coordination } \\
\text { Spatial perception }\end{array}$ & $\begin{array}{l}\text { 1. Rolling the ball } \\
\text { 2. Hold the ball with both hands and roll to hit } \\
\text { the bowling pin } \\
\text { 3. Hold the ball with one hand and set the } \\
\text { bowling pin } \\
\text { 4. Roll the ball with one hand while stepping to } \\
\text { hit the bowling pin }\end{array}$ & & \\
\hline & & $\begin{array}{l}\text { Kick } \\
\text { (ball) }\end{array}$ & $\begin{array}{l}\text { Eye-foot coordination } \\
\text { Speed perception } \\
\text { Time perception } \\
\text { Direction perception } \\
\text { Body perception }\end{array}$ & $\begin{array}{l}\text { 1. Kick a ball in place (Toe, foot inside, back of } \\
\text { foot) } \\
\text { 2. Kick the ball while running } \\
\text { 3. Kick the ball in front of you (front, side) } \\
\text { 4. Move left and right to kick }\end{array}$ & & \\
\hline & & $\begin{array}{l}\text { Bounce } \\
\text { (gym } \\
\text { ball) }\end{array}$ & $\begin{array}{l}\text { Eye-hand coordination } \\
\text { Eye-hand-foot } \\
\text { coordination } \\
\text { Spatial perception }\end{array}$ & $\begin{array}{l}\text { 1. bounce by pressing the ball with both hands } \\
\text { 2. Bounce the Ball with One Hand } \\
\text { 3. Bounce the ball alternately } \\
\text { 4. Move and bounce the ball (two hands, one } \\
\text { hand) }\end{array}$ & & \\
\hline & & $\begin{array}{l}\text { Hit } \\
\text { (racket) }\end{array}$ & $\begin{array}{l}\text { Eye-hand coordination } \\
\text { Eye-hand-foot } \\
\text { coordination } \\
\text { Height perception } \\
\text { Direction perception } \\
\text { Speed perception }\end{array}$ & $\begin{array}{l}\text { 1. Hit the throwing shuttlecock } \\
\text { 2. Hit the shuttlecock up and down } \\
\text { 3. Hit up / down according to the throwing } \\
\text { shuttlecock height } \\
\text { 4. Move left and right to hit }\end{array}$ & & \\
\hline & & $\begin{array}{l}\text { Hit } \\
\text { (baseball } \\
\text { bat) }\end{array}$ & $\begin{array}{l}\text { Eye-hand coordination } \\
\text { Height perception }\end{array}$ & $\begin{array}{l}\text { 1. Push the ball on the T-bar } \\
\text { 2. Hit the ball on the T-bar } \\
\text { 3. Rotate upper body } \\
\text { 4. Move your weight and hit the ball }\end{array}$ & & \\
\hline Cool down & Stretching & & & & & 5 \\
\hline
\end{tabular}




\section{결과}

지각운동 프로그램을 32주간 실시한 후 조작능력, 이동능력, 안정능력을 검사한 결과는<Table 5>에 제 시하였다.

\section{조작능력 기술}

조작능력 기술에서 던지기는 1점에서 4점(3점, $60 \%$ ), 받기는 0점에서 3점(3점, $60 \%$ ), 차 기는 0점에 서 4점(4점, 80\%), 치기는 1점에서 4점(3점, 60\%), 튀 기기는 1점에서 5점(4점, $80 \%)$, 굴리기는 1점에서 4점 (3점, $60 \%$ )으로 조작능력 기술 6개 영역에서 모두 향 상되었다.

\section{이동능력 기술}

이동능력 기술에서 평균대는 0점에서 4점(4점, $80 \%$ ), 뒤로 걷기에서는 0점에서 5점(5점, 100\%)으로 이동능력 기술 2 개 영역에서 모두 향상되었다.

\section{안정능력 기술}

안정능력 기술에서 외발서기는 1점에서 5점(4점, $80 \%$ ), 피하기는 0점에서 5점(5점, $100 \%$ )으로 안정 능력 기술 2 개 영역에서 모두 향상되었다.

\section{논의}

이 연구는 지각운동 프로그램이 지적장애 아동의 기 본운동기술에 미치는 영향을 알아 보고자 하였으며 연 구의 결과 조작능력, 이동능력 그리고 안정능력의 기
본운동기술 개선에 긍정적인 효과가 있는 것으로 나타 났다. 따라서 이 연구에서 사용된 지각운동 프로그램 은 지적장애 아동의 기본운동기술을 개선시킬 가능성 이 시사되었다.

이 연구에서 조작능력 기술의 결과 던지기 $(60 \%)$, 받 기(60\%), 차기(80\%), 치기(60\%), 튀기기(80\%), 굴리기 (60\%) 6 개 영역 모두 향상되었다. 이 연구와 유사한 선 행연구를 살펴보면 Jang et al. [17]은 자폐성장애 아동 과 청소년을 대상으로 지각운동 프로그램을 적용하여 조 작능력, 이동능력 그리고 안정능력이 향상되었다고 보고 하였고, Lee et al. [18] 은 발달장애 유아를 대상으로 지각운동과 기능중심의 신체활동을 수행하여 물체조작 운동기술의 6개(치기, 제자리튀기기, 받기, 차기, 던지 기, 굴리기) 영역에서 긍정적으로 개선되었다고 보고하 였으며, Lee et al. [19] 등은 자폐성장애 아동을 대상 으로 체육활동을 통하여 공 던지기, 튀기기, 받기, 차기 와 같은 조작능력 기술이 향상되었다고 보고하여 이 연 구의 결과와 일치하는 것으로 나타났다.

조작능력 기술을 향상시키기 위한 주된 요인은 신체 지각, 높이지각, 세기지각, 방향지각, 속도지각 및 공간 지각 활동과 눈-손-발의 협응활동이다[17]. 다시 말하 면 운동능력을 발휘하기 이전에 최소한의 인지능력은 기본적으로 갖추고 있어야 하며 신체에 대한 명칭과 움 직임에 대한 이해 그리고 앞과 뒤, 오른쪽과 왼쪽, 높음 과 낮음과 같은 위치에 대한 이해가 선행되어야 한다고 생각한다. 이 연구에서 제시한 지각운동 프로그램의 준 비운동에는 신체명칭 익히기와 신체범위 및 움직임 활 동을 수업 시간마다 반복적으로 인지할 수 있도록 지도

\begin{tabular}{|c|c|c|c|c|c|}
\hline Index & Exercise & Pre & Post & Increase & Rate \\
\hline \multirow{6}{*}{ Operational skills } & throwing(score) & 1 & 4 & 3 & $60 \%$ \\
\hline & catching (score) & 0 & 3 & 3 & $60 \%$ \\
\hline & kicking (score) & 0 & 4 & 4 & $80 \%$ \\
\hline & Hitting (score) & 1 & 4 & 3 & $60 \%$ \\
\hline & bouncing (score) & 1 & 5 & 4 & $80 \%$ \\
\hline & rolling (score) & 1 & 4 & 3 & $60 \%$ \\
\hline \multirow{2}{*}{ Movement skills } & balance beam(score) & 0 & 4 & 4 & $80 \%$ \\
\hline & walking backward(score) & 0 & 5 & 5 & $100 \%$ \\
\hline \multirow{2}{*}{ Stabilization skills } & standing with one leg(score) & 1 & 5 & 4 & $80 \%$ \\
\hline & escaping(score) & 0 & 5 & 5 & $100 \%$ \\
\hline
\end{tabular}


하였으며 이러한 결과 단어의 개념정리를 머리가 아닌 실제 신체를 통한 반복학습으로 얻어진 결과로 생각한 다. 조작능력 중 받기 능력의 경우 향상도 측면에서는 다른 변인들에 비해 효과가 적은 것으로 나타났다. 이 러한 결과는 공에 대한 두려움에 기반한 운동 중 낮은 집중력과 이로 인한 과제 참여시간의 감소, 문제행동 및 무반응으로 인해 과제수행에 어려운 점이 일부 있었으 며, 무엇보다도 기존의 경험에 의해 무의식적으로 습득 해온 불완전한 조작능력 기술들을 새롭게 수정하고 교 정하는 과정이 다른 변인과 비교하여 향상의 폭이 적고 더 오랜 시간이 소요된 것으로 생각한다. 대상자는 운동 초기 1 8주 동안 공에 대한 두려움이 많아 적응과정에 어려움이 많았다. 과거 공에 대한 안 좋은 경험으로 인 하여 공에 대한 두려움이 강하게 나타났고 이러한 이유 로 주어진 과제를 회피하려는 행동으로 자리이탈의 빈 도가 높았으며 심지어 적극적인 거부의사의 표현으로 바 닥에 침을 뱉거나 주먹을 쥐고 몸을 부르르 떨면서 지도 자에게 위협을 가하는 모습이 자주 관찰되었다. 특히, 공 받기 동작에서 문제행동의 표출빈도가 높이 나타났 으나 9주차부터 공에 대한 두려움을 해소하기 위한 긍 정적 심리자극의 적응과정을 통하여 공에 익숙해진 이 후로 수업의 활동수준과 참여도가 향상되었다. 이 연구 의 결과로 볼 때 지각운동 프로그램이 지적장애 아동의 기본개념에 대한 이해도를 높이고, 반복활동과 응용활 동을 통하여 조작능력 기술에 긍정적인 효과가 있을 것 이라 생각한다.

이동능력 기술인 평균대와 뒤로걷기에서 운동 후 각 각 $80 \%, 100 \%$ 로 향상되었다. 선 행연구를 살펴보면 Lee t al. [18]은 자폐성장애 아동을 대상으로 유아체 육 프로그램을 수행한 후 평균대 걷기선 따라 뒤로 걷 기, 유니바 뛰어넘기, 갤로핑과 같은 이동형 운동영역에 서 향상되었다고 보고하였고, Joo \& Han [20]은 자폐 성장애 아동을 대상으로 동작개념화 교육을 적용한 운 동을 실시하여 이동기술능력에 긍정적인 영향을 미치는 것으로 보고하였으며, 또한 Choi \& Kim[21]은 자폐성 장애 아동을 대상으로 평형성 활동 프로 그램을 실시한 결과 이동운동기술이 유의하게 향상되었다고 보고하여 이 연구의 결과와 일치하는 것으로 나타났다. 이동능력 기술을 발달시키기 위해서는 신체지각, 방향 및 공 간 지각 그리고 평형성 활동의 협응과정이 필요하다. 대 상자는 평균대에서 사전측정 시 균형을 유지하지 못하
고, 두려움에 바로 뛰어내리거나 거부하는 수준이었다. 게다가 시선처리에 어려움이 있어 10 초 이상의 집중을 필요로 하는 운동에 어려움을 보였다. 하지만 32 주간의 지각운동 프로그램을 진행한 후 평형유지와 규칙준수에 대한 능력이 향상되어 이동능력에 긍정적인 영향을 미 쳤다고 생각된다. 이러한 결과는 체력운동 및 지각운동 을 통해 신체 움직임에 대한 이해와 더불어 상지를 이 용하여 중심을 잡는 신체 조절능력이 향상되었고 손-발 의 협응성 향상, 시선처리 및 주의집중력이 향상이 되어 이동능력에 긍정적인 영향을 준 것으로 생각한다. 또한 전/후, 좌/우, 넓게/좁게, 사물과의 관계와 같은 공간지 각 및 방향지각에 대한 능력이 향상되었으며 무엇보다도 평균대 활동을 통한 균형감각 향상으로 인해 평균대 걷 기와 뒤로 걷기 영역에 큰 도움을 준 것 으로 생각한다.

안정능력 기술은 외발서기와 피하기에서 운동 후 각 각 $80 \%, 100 \%$ 로 향상되었다. 선행 연구를 살펴보면 Park \& Shim [22]은 볼을 이용한 운동 프로그램을 통 하여 외발서기, 윗몸앞으로굽히기, 앞구르기, 공피하기 에서 유의하게 향상되었다고 보고하였고, Lee et al, [18]은 유아체육 프로그램을 실시한 결과 외발서기, 체 전굴, 앞구르기, 공 피하기와 같은 안정형 운동영역에서 모두 유의한 변화가 나타났다고 보고하여 이 연구의 결 과와 견해를 같이 하는 것으로 생각한다. 이 연구의 사 전측정에서 대상자는 양팔을 활용하여 균형을 유지하는 데 어려움이 있어 균형을 잃고 넘어지는 경우가 많았다. 또한 날아오는 공을 두려워하며 손으로 공을 막거나 뒤 돌아서 눈을 감아버리는 모습이 관찰되었다. 이러한 모 습은 공을 잡는 눈과 손의 협응과정의 문제라기 보다는 공을 대하는 경험의 부족과 더불어 장시간 반복학습의 부재로 인한 것으로 생각한다. 비록 초기 1-8주간 공 에 대한 적응 운동기간이 장시간 지속되었지만 그럼에 도 불구하고 두려움이 사라짐과 동시에 적극적인 모습 으로 수업을 즐기는 모습에서 가능성을 확인할 수 있었 다. 또한, 8주 이후에는 지각운동 프로그램을 진행 할 수록 공을 주시하는 능력은 향상되었으며 공을 손으로 막는 문제행동들의 노출 빈도가 줄어들어 결국 안정능 력에 긍정적인 영향을 미쳤다고 생각한다. 이처럼 안정 능력의 외발서기와 공피하기 영역을 개선시킬 수 있었 던 주 요인은 신체지각, 눈-손-발의 협응성, 공간지각, 방향지각, 높이지각, 시간지각 그리고 평형활동이다. 이 러한 결과는 이 연구에서 제시하고 있는 체력운동과 지 
각운동 프로그램을 통해 신체 부위별 움직이는 방법을 학습하고 평형성 유지 시 상지를 활용하여 중 심잡는 신 체조절능력의 향상과 사물과의 거리감각 그리고 날아오 는 공을 끝까지 주시하 는 능력이 향상되어 결과적으로 안정능력에 긍정적인 영향을 미쳤다고 생각된다. 또한 전/후, 좌/우, 빠르게/느리게, 높낮이를 알 수 있는 높 이지각, 방향 및 시간지각 활동을 통해 자신의 몸을 어 느 타이밍에 맞춰 어느 방향으로 이동해야 하는 능력이 향상되었으 며 눈-손-발의 협응성 및 균형능력 향상으 로 인해 외발서기 및 피하기 영역에서 긍정적 인 영향을 주었다고 생각된다. 특히 지적장애 아동을 지도하는 운 동사는 아동이 초기에 한번 학습된 동작이 매우 오랫동 안 유지될 수 있으며 기존에 한번 잘못 학습 동작을 수 정하는 과정이 매우 복잡하므로 초기학습에 매우 관심 을 가져야 할 것으로 생각한다.

\section{결론}

이 연구는 지적장애 아동 1 명을 대상으로 32 주간 심 층적으로 지각운동 프로그램을 적용하여 조작능력(던지 기, 받기, 차기, 치기, 튀기기, 굴리기), 이동능력(평균대, 뒤로걷기), 안정능력(외발서기, 피하기) 영역에서 개선 되는 변화가 있었음을 확인하였다. 따라서 이 연구의 결과를 바탕으로 지각운동이 지적장애 아동의 기본운동 기술 향상에 긍정적인 효과를 볼 수 있었다. 하지만 이 연구는 지적장애 아동 1 명을 대상으로 한 사례연구 이 므로 모든 지적장애 아동을 위한 운동 프로그램으로 일 반화 하는데 한계가 있으며, 향후 연구에서는 더 많은 대상자를 중심으로 지각운동 프로그램의 효용성을 밝 히고 검증할 필요가 있을 것으로 생각한다. 또한 장애 아동 특성상 운동 중 문제행동이 반복적으로 발생하므 로 사전상황에 대한 원인규명을 보다 철저하게 분석해 야 할 필요가 있다고 생각한다.

\section{Conflicts of Interest}

The authors declare no conflict of interest.

\section{References}

1. Kim CH, Paik EH, Park MH, Wungu E. The effects of positive behavior support (PBS)intervention for a student with mental retardation. 2008;43(3):193-209.

2. Choi SK, Kang YS, Kim KI. Adapted physical education. Seoul, Rainbowbooks. 2015.

3. Sherrill C. Adapted physical activity, recreation and sport: cross disciplinary and lifespan(6th ed.). Boston, MA: WCB McGraw-Hill. 2004.

4. Cratty BJ. Adapted physical education for handicapped children and youth. Denver colorado: Love Publishing Company. 1980.

5. Carpon J. Perceptual motor development. Belmont, Ca: Fearon Pitman. 1975.

6. Hatzitaki V, Zlsi V, Kollias I, Kioumourtzoglou E. Perceptual-motor contributions to static and dynamic balance control in children. Journal of Motor Behavior. 2002;34(2):161-170.

7. Lee YC, Choi MR, Roh SY, J ong BJ. The effects of exercise program on objective control skill of elementary school students with intellectual disability. Journal of Korean Physical Education Association for Girls and Women, 2011;25(2):81-90.

8. Jeong DY. Perceptual-motor development characteristics of mentally retarded children. 1988, MS. dissertation, Daegu university.

9. Kephart NC. The slow learner in the classroom. Columbus. Ohio: Charles E, Merrill Publishing Company. 1971.

10. Lee SY, Han KK. Effects of the combined exercise program on attention of children with autism spectrum disorders. Journal of Special Education. 2019;24: 43-66.

11. Lee EK, Hong YJ, Jeong BJ. The effect of perceptualmotor function as adapted physical activities on grossmotor skills in preschool children with developmental disorder and the characteristics of motor development stages. Korean Society Adapted Physical Activity and Exercise. 2011;19(3): 89-102.

12. Burton AW, Miller DE. Movement skill Assessment. Human Kinetics. 1998.

13. Choi JH, Choi SJ. Effect of taekwon gymnastic program on exercise coordination in children with developmental disorder. The Korean Journal of Elementary Physical Education. 2017;23(3):229-243.

14. Kang YS, Roh HK. Inquiry on Trends of Qual tat ve 
Research in Adapted Physical Activity. Korean Society Adapted Physical Acti ity and Exercise. 2009;17(3), 285310.

15. You YH, Jeong YT. Effectiveness of pa ticipating TGMD-2 basis program for intellectual \& development disability in brain quotient and exercise perform capability. Korean Society Adapted Physical Activity and Exercise. 2015;23(1):49-63.

16. Ulrich DA. The test of gross motor development(2nd ed). Austin, TX:Por-ed. 1999.

17. Jang SS, Byeon JM, Lee SI, Song SH. Effects of perceptual exercise program on basic motor skills in children and adolescents with autism disorder. Korean journal of growth and development. 2019;27(3);1-11.

18. Lee KK, Han SS, Park TS, Shim JH. Effects of physical education program on fundamental motor ability changes in the autistic children. Korean journal of growth and development. 2004;12(4);79-90.
19. LEE KK, Park TS, Lee DJ, Shim JH. The effects of physical activity programs on problematic behaviors in children with autism. Korean journal of growth and development. 2008;16(3);207-214.

20. Joo MS, Han MK. The influence of movement conceptualization education on the exercise performance of children with autistic disorder. Korean Society Adapted Physical Activity and Exercise. 2010;18(3):139-154.

21. Choi MK, Kim KI. The effects of balance activity program on locomotor skills of children with autistic disorder. Korean Society Adapted Physical Activity and Exercise. 2005;13(2):81-95.

22. Park TS, Shim JH. A study on how ball sports program affects development of fundamental motor ability in preschool child en. Korean journal of growth and development. 2004;12(2);107-119. 